\title{
Failure of population recovery in relation to disease in Pacific herring
}

\author{
Gary D. Marty ${ }^{1,4, *}$, Peter-John F. Hulson ${ }^{2}$, Sara E. Miller ${ }^{2}$, Terrance J. Quinn II $^{2}$, \\ Steve D. Moffitt ${ }^{3}$, Richard A. Merizon ${ }^{3}$ \\ ${ }^{1}$ Department of Anatomy, Physiology, and Cell Biology, School of Veterinary Medicine, \\ University of California, 1 Shields Ave., Davis, California 95616-8732, USA \\ ${ }^{2}$ Juneau Center, School of Fisheries and Ocean Sciences, University of Alaska Fairbanks, \\ 17101 Pt. Lena Loop Rd., Juneau, Alaska 99801, USA \\ ${ }^{3}$ Alaska Department of Fish and Game, PO Box 669, Cordova, Alaska 99574-0669, USA \\ ${ }^{4}$ Present address: Animal Health Centre, Ministry of Agriculture and Lands, 1767 Angus Campbell Rd., \\ Abbotsford, British Columbia V3G 2M3, Canada
}

\begin{abstract}
Following an estimated $60 \%$ decline in population abundance in early 1993, recovery of the Pacific herring Clupea pallasii population of Prince William Sound, Alaska, USA, has been impaired by disease. Comprehensive epidemiological study from 1994 through 2002 validated an age-structured assessment (ASA) model of disease and population abundance; from 2003 to 2006, the impact of disease was modeled by analyzing only 2 lesions: ulcers and white foci in the heart. The ASA model identified increased natural mortality since 1993 that can be explained by (1) epidemics associated with ulcers (prevalence about $3 \%$ ) and the North American strain of viral hemorrhagic septicemia virus (VHSV Type IVa; prevalence up to 14\%) in 1994 and 1998 and (2) relatively high prevalence of the mesomycetozoean Ichthyophonus hoferi from 1994 through 2006, including epidemics with the greatest sample prevalence in 2001 (38\%, by histopathology) and 2005 (51\%, estimated histopathology prevalence). Fourteen other parasites occurred at prevalence $>10 \%$, but none were considered significant contributors to fish mortality. We predict that if natural mortality after 1994 had returned to background levels that best fit the model from 1980 to $1992\left(0.25 \mathrm{yr}^{-1}\right)$, population biomass in 2006 would have been 3 times the best estimate, despite relatively poor recruitment since 1994. In conclusion, disease information can be used to explain and predict changes in populations that have confounded traditional fisheries assessment.
\end{abstract}

KEY WORDS: Pacific herring · Clupea pallasii • Viral hemorrhagic septicemia virus · VHSV Type IVa • Ulcers · Ichthyophonus hoferi · Age-structured assessment model · Population-level response

Resale or republication not permitted without written consent of the publisher

\section{INTRODUCTION}

Epidemics in wild fish populations have been attributed to viruses (Lumsden et al. 2007, Whittington et al. 2008), bacteria (Overton et al. 2003), mesomycetozoea (Daniel 1933, Sindermann 1958, Gozlan et al. 2005), and parasites (Heggberget \& Johnsen 1982). These pathogens also occur in healthy populations (Skall et al. 2005), but little is known about the effects of endemic diseases on population-level survival and recruitment (of young fish into the population) over time.
The population dynamics of Pacific herring Clupea pallasii make it a good model species for studying disease in marine fish. Pacific herring are schooling fish that range throughout coastal regions of the North Pacific. Along with other members of the order Clupeiformes (sardine, anchovy, menhaden, and shad), they are an important component of marine ecosystems as secondary consumers and as high-quality prey for many marine birds and mammals (Womble et al. 2005, Suryan et al. 2006). In Prince William Sound, Alaska, USA, Pacific herring first spawn when they 
are 3 to 5 yr old, live for about $12 \mathrm{yr}$, and weigh up to about $250 \mathrm{~g}$. Mature fish spawn every year, but for reasons probably related to environmental conditions (Williams \& Quinn 2000), strong year-classes recruit into the adult population only about once every $4 \mathrm{yr}$. The most accurate biomass estimates are made in early spring, when fish aggregations move to shallow waters to spawn. After spawning, fish disperse and do not reaggregate near spawning areas until late fall. Feeding is minimal during the winter (Foy \& Norcross 2001).

Four years after the March 1989 'Exxon Valdez' oil spill in Prince William Sound, about $60 \%$ of the Pacific herring population died during the winter of 1992/1993. Death was attributed to poor food availability in 1992, which resulted in poor fish condition the following winter (Pearson et al. 1999, Elston \& Meyers 2009). The weakened fish had 2 types of lesions or pathogens that are commonly associated with population stress: (1) cutaneous ulcers and (2) the North American strain of viral hemorrhagic septicemia virus (VHSV Type IVa) (Meyers et al. 1994, Pearson et al. 1999, Carls et al. 2002). An alternative hypothesis attributes a greater proportion of the population decline to oil toxicity and overfishing in years leading up to the crash (Thorne \& Thomas 2008). Regardless of the original cause of the decline, $20 \mathrm{yr}$ after the oil spill, Pacific herring remain the only fish population in Prince William Sound classified as 'not recovering' by the Exxon Valdez Oil Spill Trustee Council (www.evostc.state.ak.us/recovery/status.cfm; accessed 7 January 2010).

In 1994, we initiated a 13 yr comprehensive study to determine why the population crashed and then failed to recover (Marty et al. 1998, 2003, Quinn et al. 2001). Our primary hypothesis before the study began in 1994 'was that VHSV was the most important cause of mortality, but the study was designed to identify other pathogens' (Marty et al. 1998, p. 16). Based on results from 1994, we concluded that (1) 'VHSV was a major cause of morbidity in Pacific herring' (p. 35), (2) 'we had some evidence for association of VHSV with ulcers (i.e. focal skin reddening)' (p. 35), and (3) Ichthyophonus hoferi was 'a major cause of mortality' (Marty et al. 1998, p. 36). After the first 5 yr of study (from 1994 to 1998), we hypothesized that disease information could be used to improve our ability to estimate and predict population biomass. Therefore, the age-structured assessment (ASA) model that was already in use for estimating population biomass and making management decisions was modified using disease data. The first analysis (using disease information from 1994 to 1998) indicated that 'VHSV information enhanced model fit when compared to a constant natural mortality model' (Quinn et al. 2001, p. 363), but 'the true effect of higher VHSV prevalence on natural mortality and spawning biomass cannot yet be unambiguously determined' (Quinn et al. 2001, p. 363). At that time, I. hoferi prevalence input did not significantly improve the model, and ulcer prevalence was not used. The importance of ulcers independent of VHSV became more obvious after $2 \mathrm{yr}$ of additional comprehensive study. High ulcer prevalence occurred only in years with relatively high VHSV prevalence, but VHSV prevalence was not correlated with ulcer prevalence (Marty et al. 2003). Using disease data from 1994 to 2000, VHSV prevalence alone was no longer significant; instead, mortality was best estimated 'using a disease index that combines the prevalence of [VHSV] with the prevalence of ulcers' (Marty et al. 2003, p. 1258). Still, 'changes in I. hoferi prevalence were not related to changes in population abundance' (Marty et al. 2003, p. 1258). The next published analysis (Hulson et al. 2008) focused on aspects of the model other than disease. Although details of disease prevalence were not reported, the best model - among several alternatives that included disease information from 1994 through 2004 - was the first in our series to include 2 separate disease indices: (1) a 'VHSV index' that was calculated in the same manner as the 'disease index' of Marty et al. (2003), except that it used only Ages 3 \& 4, and (2) an ' $I$. hoferi index' that used the prevalence of significant cases of $I$. hoferi (a subset of I. hoferi cases as determined by histopathology) in Ages 5+. Disease study continued through 2006, and the present report is the final paper summarizing project findings.

From 1994 to 2000, lack of population recovery was attributed to stress-associated disease (i.e. ulcers and VHSV), particularly in 1994 and 1998 (Marty et al. 2003). In the fall of 2000, however, the prevalence of Ichthyophonus hoferi increased. One objective of the present study was to determine-through use of an updated mathematical model-whether decreasing mortality associated with ulcer/VHSV outbreaks was replaced by increasing mortality associated with the mesomycetozoean $I$. hoferi, with peak $I$. hoferi prevalence in 2001 and 2005/2006. Two other objectives were to determine (1) whether the model could identify significant changes in population structure (e.g. age-specific disease-associated mortality) that could not be detected using linear analysis and (2) whether analysis of fish for 2 gross lesions - ulcers and white foci in the heart - was sufficient to model disease in the population from 2003 to 2006 .

\section{MATERIALS AND METHODS}

Comprehensive reporting of the effect of disease on the Pacific herring Clupea pallasii population (Prince William Sound, Alaska; Fig. S1 in the supplement at www.int-res.com/articles/suppl/d090p001_app.pdf) 
was last covered for the period 1994 through 2000 (Marty et al. 2003). Sampling and analytic methods used during an additional 2 yr of comprehensive study (fall 2000 through spring 2002; sample size in Table 1) were consistent with those used during the first $7 \mathrm{yr}$ (Marty et al. 1998, 2003, Davis et al. 1999). Over 9 yr of comprehensive study, 3653 Pacific herring were subjected to complete necropsy.

Infection with a microorganism does not necessarily equate with clinical disease. Therefore, 4 criteria were used to determine whether an organism or lesion was significant on an individual and population scale: (1) lesion severity, (2) changes in plasma chemistries, (3) confirmation of pathogenicity under controlled laboratory conditions using specific pathogen-free Pacific herring, and (4) association of changes in prevalence of the organism or lesion with changes in population biomass.

Data collection. Fish capture was designed to obtain a sample representative of the adult population in the study region and reference area. From 1994 through 2000, fish in Prince William Sound were all sampled from areas with the most abundant aggregates of fish: on the north end of Montague Island (e.g. Stockdale Harbor, Rocky Bay, and Zaikof Bay). Spring samples from 1995 through 1997 were split between prespawning fish $\left(\mathrm{n}=80 \mathrm{yr}^{-1}\right)$ and spawning/postspawning fish $\left(\mathrm{n}=160 \mathrm{yr}^{-1}\right)$; few differences were detected based on spawning status, and spring sampling thereafter was limited to spawning/postspawning fish (Table 1). Beginning in the spring of 2001 and continuing through 2006, fish numbers were more evenly distributed between the Eastern and Montague regions, and samples were collected from both regions (Table 1). At the reference area (Sitka Sound, Alaska, USA) sampling occurred from 1995 through 1997, but only in the spring (late March; Table 1). Sample number varied during the project based on resources available for the project and fish available for sampling. Most fish were captured in groups of 20 fish using nonselective methods: cast nets for spawning fish and commercial purse seines for other fish. Necropsies were conducted on fish deeply anesthetized (tricaine methane sulfonate, $\sim 300 \mathrm{mg} \mathrm{l}^{-1}$ ) within $5 \mathrm{~h}$ of capture.

Comprehensive analysis for each fish included gross examination, age determination from scales, weight measurements (body, liver, and gonad), body length, and cell culture of head kidney and spleen for virus isolation. Histopathology was done on 10 organs: liver, trunk kidney, heart, spleen, brain, gonad, gill, skin/ skeletal muscle (scored as 1 organ), stomach, and intestine/ pancreas/ mesenteric adipose tissue (scored as 1 organ). From 1994 through 1996, organ samples for virus isolation were frozen at $-80^{\circ} \mathrm{C}$ within $72 \mathrm{~h}$ of collection and later thawed for inoculation onto cell culture. Experimental evidence during that time demonstrated the potential for significant but unpredictable loss in virus titer resulting from freezing; therefore, all samples analyzed after 1996 were prepared for cell culture without previous freezing. Body weight, length, and age (from scales) determined from each fish linked our data with the historical database compiled by the Alaska Department of Fish and Game for the Prince William Sound population since the early 1970s. For all fish with severe focal skin reddening, kidney swabs were aerobically cultured for bacteria (all were negative).

Disease associated with ulcers and VHSV was estimated through use of an ulcer/VHSV index, which is calculated using the same values as the 'disease index' (Marty et al. 2003) and 'VHSV index' (Hulson et al. 2008). The name was changed to clarify the components of the index. The ulcer/VHSV index is calculated multiplying (1) the sample prevalence of severe focal skin reddening (most of which were associated with ulcers) by (2) the sample prevalence of VHSV. Because some VHSV+ fish without ulcers showed evidence of disease, the prevalence of ulcers used to calculate the disease index was limited by a lower bound of $0.5 \%$ (Marty et al. 2003). Use of the term ulcer/VHSV index makes no assumptions about the cause of the ulcers.

Gross and microscopic findings were classified and scored using standard criteria as none (0), mild/small numbers (1), moderate (2), or severe/abundant (3). For example, the external gross lesion focal reddening included ulcers and reddened proliferative or nodular lesions; scores were assigned as follows:

score $=0 ;$ nonfin surfaces had no foci of reddening score $=1$; single to multiple foci of reddening on nonfin surfaces totaled $<100 \mathrm{~mm}^{2}$; does not include ulcers

score $=2$; single to multiple foci of reddening on nonfin surfaces totaled 100 to $300 \mathrm{~mm}^{2}$; includes ulcers $<2 \mathrm{~mm}$ in diameter

score $=3$; single to multiple foci of reddening on nonfin surfaces total $>300 \mathrm{~mm}^{2}$; includes ulcers $\geq 2 \mathrm{~mm}$ in diameter.

In the first year of study (1994) some ulcers $\geq 2 \mathrm{~mm}$ in diameter but $<10 \mathrm{~mm}$ in diameter were scored as moderate, but records do not provide enough detail to change any scores for the present analysis. Therefore, the prevalence of severe focal skin reddening in 1994 underestimates the ulcer prevalence when compared to other years, but the magnitude of the bias is unknown.

The prevalence of Ichthyophonus hoferi from 1994 to 2002 was determined by histopathology of 10 organs; a fish was considered positive if any organ contained I. hoferi. Histopathology was not done after 2002; instead, I. hoferi prevalence from 2003 to 2006 was determined by gross analysis of the heart. To achieve a consistent $I$. hoferi parameter for all years of 
Table 1. Clupea pallasii. Sample dates, number sampled (n), mean age, and prevalence of common organisms in Pacific herring. Numbers in parentheses are sample sizes that are different from the sample size given for the row. VHSV: viral hemorrhagic septicemia virus; sk. m.: skeletal muscle; ND: no data

\begin{tabular}{|c|c|c|c|c|c|c|c|c|c|c|}
\hline Year & $\begin{array}{l}\text { Sample } \\
\text { date }\end{array}$ & $\mathrm{n}$ & $\begin{array}{l}\text { Mean } \\
\text { age } \\
(\mathrm{yr})\end{array}$ & $\begin{array}{l}\text { VHSV } \\
\text { (tissue } \\
\text { culture) }\end{array}$ & $\begin{array}{l}\text { Ichthyo- } \\
\text { phonus } \\
\text { hoferi }\end{array}$ & $\begin{array}{l}\text { Goussia } \\
\text { clupe- } \\
\text { arum } \\
\text { (liver) }\end{array}$ & $\begin{array}{l}\text { Ceratomyxa } \\
\text { auerbachi } \\
\text { (gall- } \\
\text { bladder) }\end{array}$ & $\begin{array}{l}\text { Epi-- } \\
\text { thelio- } \\
\text { cystis } \\
\text { (gill) }\end{array}$ & $\begin{array}{l}\text { Ciliated } \\
\text { proto- } \\
\text { zoa } \\
\text { (gill) }\end{array}$ & $\begin{array}{l}\text { Mono- } \\
\text { gen- } \\
\text { ean } \\
\text { (gill) }\end{array}$ \\
\hline \multicolumn{11}{|c|}{ Spring samples, Prince William Sound } \\
\hline 1989 & Apr $11-14$ & $40^{\mathrm{a}}$ & ND & ND & $13^{\mathrm{a}}$ & $63^{\mathrm{a}}$ & ND & ND & ND & ND \\
\hline 1990 & ND & ND & ND & ND & ND & ND & ND & ND & ND & ND \\
\hline $1991^{\mathrm{a}}$ & Apr 6-7 & 59 & 7.3 & ND & $3.4^{\mathrm{c}}$ & 54 & ND & ND & ND & ND \\
\hline $1992^{\mathrm{e}}$ & Apr $11,21,22$ & 105 & 4.7 & ND & 5.7 & 53 & ND & ND & ND & ND \\
\hline $1993^{\mathrm{f}}$ & Apr 20-22 & 79 & ND & $\begin{array}{l}3 \text { of } 4 \\
5 \text {-fish pools+ }\end{array}$ & 5.1 & 41 & ND & ND & ND & ND \\
\hline $1994^{\mathrm{g}}$ & Apr $22-26$ & $212-233$ & 6.2 & 4.7 & $23.1^{\mathrm{c}}$ & $71.2^{\mathrm{c}}$ & $18.7(171)$ & 10.8 & 11.8 & 12.7 \\
\hline $\begin{array}{l}1995 \text { adults } \\
\text { Prespawn juvenile } \\
\text { Prespawn adults } \\
\text { Spawning }\end{array}$ & $\begin{array}{cc} & \text { Apr 11, 24-27 } \\
\text { es } & \text { Apr 11 } \\
\text { Apr 11 } \\
\text { Apr 24-27 }\end{array}$ & $\begin{array}{c}221 \\
39 \\
41 \\
180\end{array}$ & $\begin{array}{l}6.2 \\
2.0 \\
4.1 \\
6.6\end{array}$ & $\begin{array}{c}2.3 \\
0.0 \\
12.2 \\
0.0\end{array}$ & $\begin{array}{c}21.7 \\
5.1 \\
19.5 \\
22.2\end{array}$ & $\begin{array}{l}71.9 \\
56.4 \\
78.0 \\
70.6\end{array}$ & $\begin{array}{c}36.6(213) \\
11.8(34) \\
23.7(38) \\
39.4(175)\end{array}$ & $\begin{array}{l}19.9 \\
23.1 \\
41.5 \\
15.0\end{array}$ & $\begin{array}{l}1.4 \\
0.0 \\
2.4 \\
1.1\end{array}$ & $\begin{array}{c}9.0 \\
0.0 \\
2.4 \\
10.6\end{array}$ \\
\hline $\begin{array}{l}1996 \text { adults } \\
\text { Prespawning } \\
\text { Spawning }\end{array}$ & $\begin{array}{c}\text { Apr } 7-8,19-21 \\
\text { Apr } 7-8 \\
\text { Apr } 19-21\end{array}$ & $\begin{array}{c}260 \\
80 \\
180\end{array}$ & $\begin{array}{l}5.8 \\
5.2 \\
6.1\end{array}$ & $\begin{array}{l}0.0 \\
0.0 \\
0.0\end{array}$ & $\begin{array}{l}20.4 \\
12.5 \\
23.9\end{array}$ & $\begin{array}{c}80 \\
78.8 \\
80.6\end{array}$ & $\begin{array}{l}29.1(251) \\
35.9(78) \\
26.0(173)\end{array}$ & $\begin{array}{l}16.5 \\
27.5 \\
11.7\end{array}$ & $\begin{array}{l}0.4 \\
0.0 \\
0.6\end{array}$ & $\begin{array}{l}1.5 \\
1.3 \\
1.7\end{array}$ \\
\hline $\begin{array}{l}1997 \text { adults } \\
\text { Prespawning } \\
\text { Spawning }\end{array}$ & $\begin{array}{c}\text { Mar 29-30, Apr 12-14 } \\
\text { Mar 29-30 } \\
\text { Apr 12-14 }\end{array}$ & $\begin{array}{c}260 \\
80 \\
180\end{array}$ & $\begin{array}{l}5.4 \\
4.5 \\
5.9\end{array}$ & $\begin{array}{l}14.6 \\
13.8 \\
15.0\end{array}$ & $\begin{array}{l}16.2 \\
13.8 \\
17.2\end{array}$ & $\begin{array}{c}69 \\
66.3 \\
70.6\end{array}$ & $\begin{array}{l}20.4(250) \\
16.7(78) \\
22.1(172)\end{array}$ & $\begin{array}{l}35.8 \\
42.5 \\
32.8\end{array}$ & $\begin{array}{l}0.0 \\
0.0 \\
0.0\end{array}$ & $\begin{array}{l}7.7 \\
5.0 \\
8.9\end{array}$ \\
\hline 1998 & Apr 15-18 & 250 & 4.7 & 13.6 & 17.6 & 73 & $50.6(247)$ & 29.6 & 4.4 & 12.4 \\
\hline 1999 & Apr 13-18 & 300 & 6.1 & 1.0 & 24.3 & 85 & $28.2(298)$ & 23.0 & 2.7 & 11.3 \\
\hline 2000 & Apr $14-18$ & 300 & 6.2 & 0.0 & 21.7 & 78 & $18.1(298)$ & 11.0 & 3.0 & 11.7 \\
\hline $\begin{array}{l}2001 \text { all fish } \\
\text { Eastern region } \\
\text { Montague region }\end{array}$ & $\begin{array}{l}\text { Apr } 10-14 \\
\text { Apr 10-12 } \\
\text { Apr 13-14 }\end{array}$ & $\begin{array}{l}300 \\
220 \\
80\end{array}$ & $\begin{array}{l}5.7 \\
5.6 \\
6.2\end{array}$ & $\begin{array}{l}1.7 \\
2.3 \\
0.0\end{array}$ & $\begin{array}{l}38.0 \\
35.9 \\
43.8\end{array}$ & $\begin{array}{c}80 \\
82.3 \\
75.0\end{array}$ & $\begin{array}{c}15.5(296) \\
17.1(216) \\
11.3\end{array}$ & $\begin{array}{l}23.3 \\
21.8 \\
27.5\end{array}$ & $\begin{array}{l}1.7 \\
2.3 \\
0.0\end{array}$ & $\begin{array}{l}3.0 \\
3.2 \\
2.5\end{array}$ \\
\hline $\begin{array}{l}2002 \text { all fish } \\
\text { Eastern region } \\
\text { Montague region }\end{array}$ & $\begin{array}{l}\text { Apr } 12-15 \\
\text { Apr } 12-14 \\
\text { Apr } 14-15\end{array}$ & $\begin{array}{l}300 \\
200 \\
100\end{array}$ & $\begin{array}{l}4.0 \\
4.0 \\
3.9\end{array}$ & $\begin{array}{c}14.0 \\
7.5 \\
27.0\end{array}$ & $\begin{array}{l}15.0 \\
14.5 \\
16.0\end{array}$ & $\begin{array}{c}79 \\
80.5 \\
77.0\end{array}$ & $\begin{array}{c}5.0(299) \\
5.0 \\
5.1(99)\end{array}$ & $\begin{array}{l}38.7 \\
36.5 \\
43.0\end{array}$ & $\begin{array}{l}0.7 \\
1.0 \\
0.0\end{array}$ & $\begin{array}{l}14.3 \\
13.0 \\
17.0\end{array}$ \\
\hline 2003 & Apr 6-7, 14 & 308 & 4.2 & $1.0^{\mathrm{i}}$ & $20.8^{\mathrm{j}}$ & ND & ND & ND & ND & ND \\
\hline 2004 & Apr 7, 10-11 & 250 & 5.1 & $1.0^{\mathrm{i}}$ & $28.4^{\mathrm{j}}$ & ND & ND & ND & ND & ND \\
\hline 2005 & Apr 5,7 & 150 & 5.7 & $1.0^{\mathrm{i}}$ & $50.6^{\mathrm{j}}$ & ND & ND & ND & ND & ND \\
\hline 2006 & Mar 28, Apr 14 & 150 & 6.2 & $1.0^{\mathrm{i}}$ & $40.0^{\mathrm{j}}$ & ND & ND & ND & ND & ND \\
\hline \multicolumn{11}{|c|}{ Spring samples, Sitka Sound } \\
\hline 1995 & Mar 25-29 & 240 & 5.1 & 0.0 & 19.6 & 73 & $32.4(216)$ & 25.0 & 1.3 & 10.8 \\
\hline 1996 & Mar 23-27 & 240 & 4.6 & 0.0 & 21.3 & 79 & $23.4(231)$ & 21.3 & 0.0 & 2.1 \\
\hline $1997^{\mathrm{k}}$ & Mar 22-26 & 250 & 4.9 & 0.8 & ND & 78 & $33.3(48)$ & ND & ND & ND \\
\hline \multicolumn{11}{|c|}{ Fall samples, Prince William Sound } \\
\hline $1990^{\mathrm{a}}$ & Oct 6,10 & 99 & 3.8 & ND & 15.0 & 60 & ND & ND & ND & ND \\
\hline $1991^{\mathrm{a}}$ & Oct $12-17$ & 48 & ND & ND & 2.1 & $40^{\mathrm{c}}$ & ND & ND & ND & ND \\
\hline 1992 & ND & ND & ND & ND & ND & ND & ND & ND & ND & ND \\
\hline 1993 & ND & ND & ND & ND & ND & ND & ND & ND & ND & ND \\
\hline 1994 & ND & ND & ND & ND & ND & ND & ND & ND & ND & ND \\
\hline 1995 & Nov $13-14$ & 130 & 3.6 & 0.0 & 16.9 & 63 & 20.8 (125) & 5.4 & 0.0 & 1.5 \\
\hline 1996 & Oct $15-17$ & 160 & 3.6 & 0.0 & 14.4 & 70 & $8.3(156)$ & 7.5 & 0.0 & 1.9 \\
\hline 1997 & Oct 30, Nov $20-22$ & 80 & 2.7 & 0.0 & 3.8 & 75 & 30.0 & 7.5 & 0.0 & 1.3 \\
\hline 1998 & Nov $10-12$ & 100 & 3.8 & 0.0 & 16.0 & 82 & 12.0 & 9.0 & 0.0 & 0.0 \\
\hline 1999 & Nov 3-5 & 40 & 5.0 & 0.0 & 17.5 & 78 & 17.5 & 7.5 & 0.0 & 0.0 \\
\hline 2000 & Oct $27-28$ & 100 & 3.0 & 0.0 & 19.0 & 84 & $13.1(99)$ & 7.0 & 0.0 & 3.0 \\
\hline 2001 & Nov 8-10 & 100 & 2.2 & 0.0 & 8.0 & 72 & 9.1 (99) & 20.0 & 0.0 & 4.0 \\
\hline
\end{tabular}

${ }^{a}$ Marty et al. (1999). b ${ }^{b}$ Moles et al. (1993). ' Numbers differ from earlier publications based on re-analysis of the slides after original publication. ${ }^{\mathrm{d}}$ Prevalence based on histopathology only; total prevalence after 1993 based on kidney touch preparations and histopathology. ${ }^{e}$ Kocan et al. (1996). ${ }^{\text {f}}$ Meyers et al. (1994), Meyers \& Winton (1995). ${ }^{9}$ Marty et al. (1998); gross analysis, kidney touch

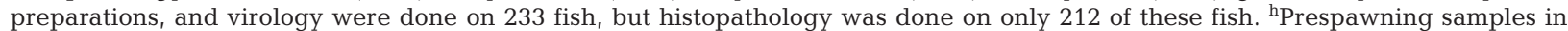
1995 included 39 juveniles; these data were not used in the 1995 summary or elsewhere. ${ }^{i}$ VHSV prevalence was not determined from 
Table 1 (continued)

\begin{tabular}{|c|c|c|c|c|c|c|c|c|c|c|}
\hline $\begin{array}{l}\text { Gross } \\
\text { parasitic } \\
\text { copepod } \\
\text { (gill) }\end{array}$ & $\begin{array}{l}\text { Ortholinea } \\
\text { orientalis } \\
\text { (renal ducts) }\end{array}$ & $\begin{array}{l}\text { Unidentified } \\
\text { myxosporean } \\
\text { (renal ducts) }\end{array}$ & $\begin{array}{c}\text { Adult } \\
\text { trematode } \\
\text { (stomach) }\end{array}$ & $\begin{array}{l}\text { Unclassified } \\
\text { coccidian } \\
\text { Goussia sp.? } \\
\text { (intestine) }\end{array}$ & $\begin{array}{l}\text { Adult } \\
\text { trematode } \\
\text { (intestine) }\end{array}$ & $\begin{array}{c}\text { Larval } \\
\text { cestode }\end{array}$ & $\begin{array}{c}\text { Gross } \\
\text { anisakid } \\
\text { nematodes } \\
\text { (viscera) }\end{array}$ & \multicolumn{2}{|c|}{$\begin{array}{l}\text { Histopathology } \\
\text { anisakid } \\
\text { nematodes } \\
\text { (intestine) (sk. m.) }\end{array}$} & $\begin{array}{l}\text { Male fish } \\
\text { Eimeria } \\
\text { sardinae } \\
\text { (testis) }\end{array}$ \\
\hline ND & ND & ND & ND & ND & ND & ND & $61^{\mathrm{b}}$ & ND & ND & ND \\
\hline ND & ND & ND & ND & ND & ND & ND & ND & ND & ND & ND \\
\hline ND & $4.3^{\mathrm{d}}$ & ND & ND & ND & ND & ND & ND & ND & ND & ND \\
\hline ND & 19.3 & 11.8 & 8.6 & 91.0 & 2.8 & 2.4 & 100 & 76 & 3.3 & $63.7^{\mathrm{c}}(102)$ \\
\hline $\begin{array}{l}\text { ND } \\
\text { ND } \\
\text { ND } \\
\text { ND }\end{array}$ & $\begin{array}{l}28.5 \\
30.8 \\
26.8 \\
28.9\end{array}$ & $\begin{array}{c}10.4 \\
7.9 \\
7.3 \\
11.1\end{array}$ & $\begin{array}{l}12.2 \\
17.9 \\
14.6 \\
11.7\end{array}$ & $\begin{array}{l}95.0 \\
97.4 \\
95.1 \\
95.0\end{array}$ & $\begin{array}{c}8.6 \\
30.8 \\
7.3 \\
8.9\end{array}$ & $\begin{array}{c}3.6 \\
23.1 \\
4.9 \\
3.3\end{array}$ & $\begin{array}{l}100 \\
100 \\
100 \\
100\end{array}$ & $\begin{array}{l}82.8 \\
82.1 \\
82.9 \\
82.8\end{array}$ & $\begin{array}{c}3.2 \\
12.8 \\
4.9 \\
2.8\end{array}$ & $\begin{array}{l}84.6(104) \\
17.6(17) \\
80.0(10) \\
85.1(94)\end{array}$ \\
\hline 58.8 & 31.6 & 15.7 & 5.6 & 96.4 & 33.6 & 2.4 & 100 & 86 & 2.8 & $73.6(140)$ \\
\hline 49.0 & 20.7 & 14.0 & 15.7 & 97.0 & 8.0 & 0.3 & 100 & 93 & 1.3 & 91.3 (149) \\
\hline 45.3 & 28.3 & 12.0 & 11.3 & 98.3 & 12.7 & 1.7 & 100 & 98 & 2.7 & $59.3(174)$ \\
\hline $\begin{array}{l}51.3 \\
50.0 \\
55.0\end{array}$ & $\begin{array}{l}32.0 \\
30.9 \\
35.0\end{array}$ & $\begin{array}{l}11.7 \\
12.7 \\
8.8\end{array}$ & $\begin{array}{c}7.7 \\
5.5 \\
13.8\end{array}$ & $\begin{array}{c}97.7 \\
96.8 \\
100.0\end{array}$ & $\begin{array}{l}4.3 \\
4.5 \\
3.8\end{array}$ & $\begin{array}{l}2.0 \\
1.8 \\
2.5\end{array}$ & $\begin{array}{l}100 \\
100 \\
100\end{array}$ & $\begin{array}{c}92 \\
91.8 \\
92.5\end{array}$ & $\begin{array}{l}2.3 \\
2.7 \\
1.3\end{array}$ & $\begin{array}{c}78.3(152) \\
74.4(121) \\
93.5(31)\end{array}$ \\
\hline $\begin{array}{l}62.0 \\
61.0 \\
64.0\end{array}$ & $\begin{array}{l}22.3 \\
22.0 \\
23.0\end{array}$ & $\begin{array}{l}15.0 \\
15.0 \\
15.0\end{array}$ & $\begin{array}{c}8.3 \\
10.5 \\
4.0\end{array}$ & $\begin{array}{l}97.0 \\
98.0 \\
95.0\end{array}$ & $\begin{array}{c}6.7 \\
5.0 \\
10.0\end{array}$ & $\begin{array}{l}7.0 \\
6.5 \\
8.0\end{array}$ & $\begin{array}{l}96.7 \\
96.5 \\
97.0\end{array}$ & $\begin{array}{c}64 \\
63.0 \\
66.0\end{array}$ & $\begin{array}{l}2.0 \\
2.5 \\
1.0\end{array}$ & $\begin{array}{c}90.3(176) \\
93.2(117) \\
84.7(59)\end{array}$ \\
\hline ND & ND & ND & ND & ND & ND & ND & ND & ND & ND & ND \\
\hline ND & ND & ND & ND & ND & ND & ND & ND & ND & ND & ND \\
\hline ND & $12^{\mathrm{d}}$ & ND & ND & ND & ND & ND & ND & ND & ND & ND \\
\hline ND & $31^{\mathrm{cd}}$ & 8.2 & ND & ND & ND & ND & ND & ND & ND & ND \\
\hline ND & ND & ND & ND & ND & ND & ND & ND & ND & ND & ND \\
\hline ND & ND & ND & ND & ND & ND & ND & ND & ND & ND & ND \\
\hline ND & ND & ND & ND & ND & ND & ND & ND & ND & ND & ND \\
\hline ND & 18.5 & 5.4 & 35.4 & 26.2 & 0.8 & 9.2 & 100 & 90 & 1.5 & $61.5(65)$ \\
\hline 61.8 & 21.9 & 5.0 & 26.9 & 15.0 & 23.8 & 35.6 & 100 & 87 & 1.9 & $43.0(79)$ \\
\hline 63.8 & 25.0 & 3.8 & 36.3 & 13.8 & 11.3 & 17.5 & 100 & 84 & 1.3 & $52.9(34)$ \\
\hline 54.0 & 10.0 & 4.0 & 17.0 & 28.0 & 11.0 & 7.0 & 100 & 95 & 3.0 & $56.6(53)$ \\
\hline 45.0 & 12.5 & 5.0 & 35.0 & 5.0 & 2.5 & 12.5 & 100 & 93 & 2.5 & $47.4(19)$ \\
\hline 68.0 & 19.0 & 2.0 & 25.0 & 44.0 & 25.0 & 11.0 & 100 & 90 & 4.0 & $44.9(49)$ \\
\hline 70.0 & 17.0 & 1.0 & 15.0 & 39.0 & 2.0 & 39.0 & 95.0 & 68 & 0.0 & $37.9(58)$ \\
\hline $\begin{array}{l}2003 \text { to } \\
\text { prevale } \\
\text { the pre } \\
\text { limited } \\
1988 \text { ye }\end{array}$ & $\begin{array}{l}\text { 006, but was as } \\
\text { ce from } 1989 \\
\text { alence of gross } \\
\text { gross examin } \\
\text { r-class only ( }\end{array}$ & $\begin{array}{l}\text { sumed the sam } \\
2002 \text { was dete } \\
\text { white foci in th } \\
\text { ation, age deter } \\
=49 \text { ) }\end{array}$ & $\begin{array}{l}\text { as in } 1999 \\
\text { rmined usir } \\
\text { e heart (les } \\
\text { mination, an }\end{array}$ & $\begin{array}{l}\text { (based on low } \\
\text { ig histopathol } \\
\text { ions character } \\
\text { d virus cultur }\end{array}$ & $\begin{array}{l}\text { ulcer prevale } \\
\text { ogy; prevaler } \\
\text { istic of } I \text {. hof } \\
\text { for all fish ( }\end{array}$ & $\begin{array}{l}\text { ence in the } \\
\text { nce for } 20 \\
\text { feri infecti } \\
(n=250),\end{array}$ & $\begin{array}{l}\text { ese years; se } \\
03 \text { through } \\
\text { ion). }{ }^{\mathrm{k}} \text { Analys } \\
\text { but histopatl }\end{array}$ & $\begin{array}{l}\text { e Table 2) } \\
2006 \text { was } \\
\text { is of Sitk } \\
\text { tology wa }\end{array}$ & $\begin{array}{l}\text { chthyop } \\
\text { imated } \\
\text { amples } \\
\text { imited t }\end{array}$ & $\begin{array}{l}\text { nus hoferi } \\
\text { doubling } \\
1997 \text { was } \\
\text { iver of the }\end{array}$ \\
\hline
\end{tabular}


study (needed for modeling purposes), the histopathology prevalence of $I$. hoferi was estimated from 2003 through 2006 by doubling each year's gross $I$. hoferi prevalence. This adjustment was based on a first-order linear regression of spring-sample data from 1997 through 2002: gross I. hoferi prevalence ( $x=7.7,10.4,13.3,11.7,18.0$, and $5.3 \%$, respectively) versus the histopathology $I$. hoferi prevalence $(y ;$ Table 1) yielded the equation $y=1.81 x+2.05\left(\mathrm{r}^{2}=\right.$ $0.89, \mathrm{p}=0.004)$; although a second-order regression better fit the data $\left(\mathrm{r}^{2}=0.99\right)$, it was not used because it was not considered reliable for extrapolating beyond the data, as needed for 2005 when gross I. hoferi prevalence was $25 \%$. As an alternate diagnostic method that was not used, heart explant cultures for $I$. hoferi are more sensitive than histopathology for detecting fish that carry I. hoferi (Kocan et al. 1999), but the relation of explant culture results to population change has not been analyzed. Statistical significance of differences in annual $I$. hoferi prevalence during outbreaks was determined using $2 \times 2$ contingency tables and Fisher's exact test.

Comprehensive study from 1994 through 2002 provided the validation needed to limit the study from 2003 through 2006 to the assessment of only 2 gross lesions. More than 100 fish health variables were analyzed from 1994 through 2002, but we hypothesized that only 3 variables were needed to estimate diseaseassociated mortality. One of these variables - VHSV prevalence (determined by cell culture)-was not analyzed from 2003 through 2006 because of limited funding and because during those years recruitment was poor, ulcer prevalence was $<1 \%$, and VHSV prevalence was probably low. In previous years with poor recruitment and low ulcer prevalence (1999 to 2001), VHSV prevalence had been low (Table 1). Therefore, after 2002, study was limited to semiquantitative scoring of (1) focal skin reddening and (2) white foci in the heart (consistent with Ichthyophonus hoferi infection). From 2003 through 2006, samples from Prince William Sound were analyzed during early spring only, near the time of spawning.

Population modeling of disease. The association of disease with population abundance was quantified by updating the ASA model (Quinn et al. 2001, Marty et al. 2003) with data from 2001 through 2006. The ASA model provides an estimation framework to integrate the various sources of infor- mation about Pacific herring in Prince William Sound from 1980 through 2006. Because the new model reestimates population parameters for all years, population estimates for a given year (e.g. 1992) are not the same in the current model as in previously published models. Data sources include age compositions from the purse-seine fishery and spawning surveys, egg production estimates from diver surveys, mile-days of milt from aerial surveys (Quinn et al. 2001), and a biomass index from hydroacoustic surveys (Hulson et al. 2008). Overall, the 6 datasets fitted in the ASA model included 333 observations, and the number of parameters among the models ranged from 40 to 48 (Table 2).

In the ASA model, observations are compared to model quantities using least-squares analysis. Details of the objective function used for parameter estimation have been previously published (Hulson et al. 2008). Least-squares components were included for the purse-seine age composition (in years when the sac roe fishery was open: 1980 to 1988,1990 to 1992,1997 to 1998), spawning age composition (since 1982), egg survey estimates on a logarithmic scale (from $10 \mathrm{yr}$ between 1984 and 1997), the milt index on a logarithmic scale (all years from 1980 to 2006), hydroacoustic biomass measurements on a logarithmic scale (1994 to 2006), and deviations from a Ricker spawner-recruit curve (Quinn \& Deriso 1999). The statistical framework of the ASA model allows estimation of parameters for recruitment, initial abundance, maturity, gear selectivity, a milt calibration coefficient, a hydroacoustic calibration coefficient, and disease coefficients.

Table 2. Clupea pallasii. Summary statistics for the data and values of the model selection criterion for 25 model scenarios applied to Prince William Sound fisheries data and disease indices. The best model of pairwise combinations of the ulcer/VHSV index with the Ichthyophonus hoferi index (bold print) has a zero value for the Delta Akaike information criterion corrected for small sample sizes $\left(\Delta \mathrm{AIC}_{\mathrm{c}}\right)$; for other models, $\Delta \mathrm{AIC}_{\mathrm{c}}<4$ is considered unimportant

\begin{tabular}{|c|c|c|c|c|c|}
\hline \multicolumn{2}{|l|}{ Variable } & \multicolumn{2}{|c|}{ Sample size } & \multicolumn{2}{|c|}{ Data weight } \\
\hline \multicolumn{2}{|c|}{ Seine age composition } & \multicolumn{2}{|c|}{88} & \multicolumn{2}{|l|}{1} \\
\hline \multicolumn{2}{|c|}{ Spawning age composition } & \multicolumn{2}{|c|}{172} & \multicolumn{2}{|l|}{1} \\
\hline \multicolumn{2}{|c|}{ Mile-days of milt } & \multicolumn{2}{|c|}{27} & \multicolumn{2}{|l|}{0.5} \\
\hline Egg deposition & & \multicolumn{2}{|c|}{10} & \multicolumn{2}{|l|}{0.5} \\
\hline Hydroacoustic & & \multicolumn{2}{|c|}{12} & \multicolumn{2}{|l|}{0.5} \\
\hline Ricker spawner-r & uit & \multicolumn{2}{|c|}{24} & \multicolumn{2}{|l|}{0.03} \\
\hline \multirow{2}{*}{$\begin{array}{l}\text { Ulcer/ } \\
\text { VHSV index }\end{array}$} & \multirow[b]{2}{*}{ Not used } & \multicolumn{3}{|c|}{ Ichthyophonus hoferi index } & \\
\hline & & $\begin{array}{l}\text { Ages } 3 \\
\& 4 \text { only }\end{array}$ & $\begin{array}{c}\text { Ages } \\
5+\text { only }\end{array}$ & $\begin{array}{c}\text { Ages } 3 \& 4 \\
\text { and Ages 5+ }\end{array}$ & All \\
\hline Not used & 93.1 & 46.6 & 23.9 & 9.7 & 2.7 \\
\hline Ages 3 \& 4 only & 46.8 & 44.9 & 4.5 & 7.0 & $\mathbf{0 . 0}$ \\
\hline Ages 5+ only & 46.6 & 25.9 & 28.4 & 15.1 & 8.0 \\
\hline $\begin{array}{l}\text { Ages } 3 \& 4 \\
\text { and Ages 5+ }\end{array}$ & 28.5 & 24.0 & 9.9 & 12.5 & 5.3 \\
\hline All & 30.2 & 23.3 & 14.2 & 14.1 & 6.8 \\
\hline
\end{tabular}


We assume that disease increases the natural mortality $M$ linearly for all adult ages (Ages 3+), or:

$$
M=M_{0}+\sum_{i} \beta_{i} x_{i t}
$$

in which $M_{0}$ is instantaneous natural mortality from sources other than disease (assumed constant), $x_{i t}$ is the $i$ th disease prevalence variable in year $t$, and $\beta_{i}$ is a disease coefficient governing the magnitude of the effect. This is a slight modification of the former model (Quinn et al. 2001, Marty et al. 2003) in which survival was linearly related to disease. The modification was made because a nonlinear relationship between survival and disease prevalence enhances estimation stability in recent versions of the model (Hulson et al. 2008).

Precise index information for disease in 1993 is not available because this was the first year in which the North American strain of VHSV was isolated from Pacific herring (Meyers et al. 1994). Nevertheless, the fishery and survey information provided clear evidence of a large increase in natural mortality after the 1992 fisheries harvest. For each index in 1993, the value $\boldsymbol{X}_{i, 1993}$ used in Eq. (1) is estimated. This is essentially equivalent to estimating 2 values of natural mortality in 1993: 1 for Ages 3 \& 4 and 1 for Ages 5+. We further postulate that these elevated natural mortalities commenced just after the spring fisheries in 1992 and continued through the fall of 1993 (18 mo).

The age-structured assessment model contains information about the Pacific herring fisheries in Prince William Sound, Alaska, which include purse-seine, gillnet, and pound fisheries in the spring (mainly for roe), and a food and bait fishery in the fall. Recruitment occurs at Age 3, and there are parameters for recruit abundance, $\left\{N_{3, t}\right\}$, for all years (and for all abundances in the first year, 1980). From these parameters and the survival model (Eq. 1), abundance at each subsequent age $a$ and year $t$ is estimated from the equation:

$N_{a+1, t+1}=\left[\left(N_{a, t}-C_{\text {seine }}-C_{\text {gill }}-C_{\text {pound }}\right) \times S_{t}^{1 / 2}-C_{\text {food }}\right] \times S_{t+1}^{1 / 2}$

where $N$ is abundance, $C$ is annual catch-at-age, and $S^{1 / 2}$ is half-year survival, calculated as the square root of $S$. In Eq. (2), we assume that the disease variable measured in years $t+1$ at the time of spawning affects the population in the last half-year of year $t$ (before recruitment, spawning, and spring fisheries) and the first half-year of year $t+1$. Another assumption is that total catch for the seine fishery and catch-at-age for the other fisheries are assumed to be measured without error in the model. The estimated number of spawners is the mature abundance after the spring fisheries, or:

$$
\text { Spawners }_{t}=\sum_{a} \operatorname{mat}_{a}\left(N_{a, t}-C_{\text {seine }}-C_{\text {gill }}-C_{\text {pound }}\right)
$$

where mat $_{a}$ is the proportion mature at age a. Spawning biomass is similar to that in Eq. (3), but also multi- plies by weight-at-age. The fit of the best model to the datasets has no unwelcome patterns in the seine or spawning age composition residuals (not shown). Further details about the ASA model are given elsewhere (Hulson et al. 2008).

Twenty-five model scenarios were constructed to examine which population processes were important in explaining Pacific herring dynamics. In the null model, disease information is not used, and natural mortality is assumed to be constant and equal to 0.25 . Indices were segregated into age groups to evaluate if a disease index was more influential on younger compared to older Pacific herring. For each index, 5 cases were used: (1) no index, (2) Age 3 \& 4 index, (3) Age 5+ index, (4) both Age $3 \& 4$ and Age 5+ indices, and (5) the pooled ages index. This resulted in 24 additional scenarios of pairwise combinations of the ulcer/VHSV index with the Ichthyophonus hoferi index.

Model scenario selection and comparison follow established procedures. To compare the models directly, we use the Akaike information criterion corrected for small sample sizes $\left(\mathrm{AIC}_{\mathrm{c}}\right.$ ) (Anderson et al. 1998, Burnham \& Anderson 1998). Hulson et al. (2008) presented details of the calculation of $\mathrm{AIC}_{\mathrm{C}}$ for the Prince William Sound Pacific herring ASA model. The difference $(\Delta)$ between a given model and the model with the lowest $\mathrm{AIC}_{\mathrm{c}}$ value is the primary statistic for choosing appropriate models. We reject models with $\Delta \mathrm{AIC}_{\mathrm{C}}>4$ and include candidate models with $\Delta \mathrm{AIC}_{\mathrm{C}} \leq 4$ (Anderson et al. 1998).

Model uncertainty in each scenario is evaluated with a bootstrap procedure similar to previous study (Quinn et al. 2001, Hulson et al. 2008). The bootstrap was performed with 1000 replications, the recommended level for calculating confidence intervals (Efron \& Tibshirani 1993), and was performed by linking data generation and compilation in $\mathrm{R}$ and model optimization in $\mathrm{AD}$ Model Builder (Fournier 1996).

To determine the best value for background mortality, $\mathrm{AIC}_{\mathrm{c}}$ analysis was done after background mortality was ranged from 0.1 to 0.4 on all model scenarios. A background mortality of 0.25 produced the best fit to observations of age composition and population indices and was used for all other analyses.

To evaluate the influence of disease on the spawning population over time, we project the population in the absence of disease. With parameters obtained from the best model (i.e. recruitment, maturity, gear selectivity) we omit mortality due to disease and subsequently project spawning population estimates in the absence of disease. Projections of the spawning biomass are made from 1993 to 2006, to evaluate the hypothesized population trajectory with no disease, and from 1995 to 2006 , to assess the population trajectory after the initial 1993/1994 epidemic. To clarify model results, recruit- 
ment estimates and age-structured estimates of abundance, biomass, deaths, and sources of mortality were calculated seasonally for all years from fall 1993 through spring 2006.

\section{RESULTS AND DISCUSSION}

\section{Significant lesions and pathogens}

Among the 16 organisms that occurred in Pacific herring Clupea pallasii at $>10 \%$ prevalence (Table 1), only Ichthyophonus hoferi and VHSV met all 4 criteria for significance at the population level (Kocan et al. 1997, 1999, Marty et al. 2003). VHSV occurred sporadically in fish sampled in the spring, but it was never cultured in any of the 710 fish sampled in the fall (Table 1). Cutaneous ulcers were also considered a significant lesion, but, because they have multiple possible causes, their significance cannot be readily tested under controlled laboratory conditions. One common cause of ulcers filamentous bacteria - is widely recognized as a cutaneous pathogen of many marine fish species (Avendaño-Herrera et al. 2006), and ulcers are considered to be fatal in Pacific herring (Elston \& Meyers 2009). Ulcer prevalence in 1995 was greater in samples from Prince William Sound than in samples from Sitka Sound (3.6 vs. $0.4 \%$ ), and, in 1997, VHSV prevalence was greater in Prince William Sound than in Sitka Sound (14.6 vs. $0.8 \%$ ). Sample prevalence of most other microorganisms, including I. hoferi, was not different in fish from Prince William Sound and Sitka Sound from 1995 to 1997 (Table 1). Prevalence of branchial cilates and monogeneans tended to be greater in years of poor fish

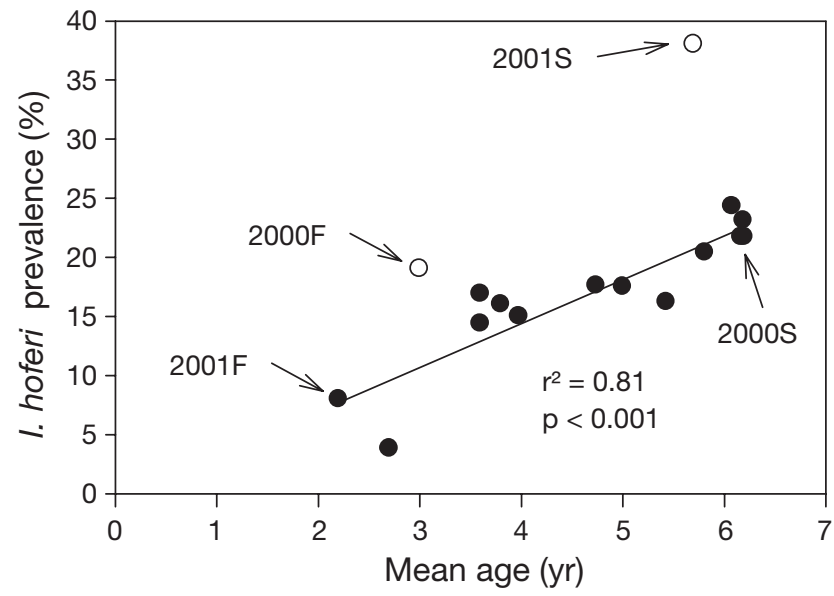

Fig. 1. Clupea pallasii. Ichthyophonus hoferi prevalence in Prince William Sound samples from the spring (1994 to 2002) and fall (1995 to 2001). The trend for age-specific prevalence of $I$. hoferi was greater during the epidemic from fall (F) 2000 through spring (S) 2001 (O) than among other samples $(\bullet$, designated by linear regression) health (e.g. 1994 and 1998; Table 1), but parasite abundance was considered too low to significantly affect fish health on a population scale (e.g. all cases had $\leq 1$ ciliate and $\leq 5$ monogeneans per gill section); instead, these parasites were thought to be taking advantage of fish compromised by other diseases.

\section{Ichthyophonus hoferi}

The prevalence of $I$. hoferi was high and significantly associated with fish age throughout the study in both spring and fall samples (Fig. 1; p < 0.001). The first
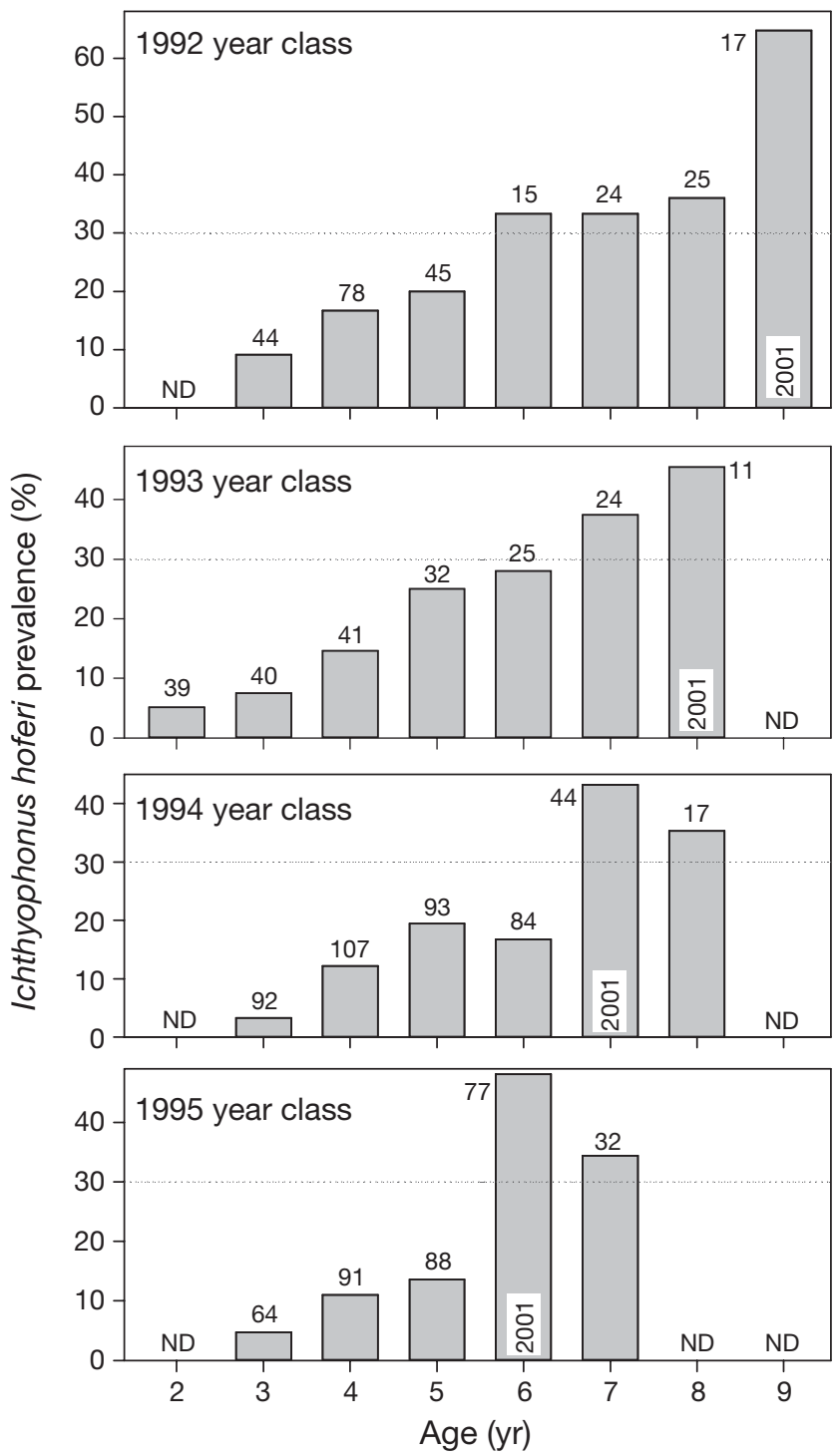

Fig. 2. Clupea pallasii. Histopathology prevalence of Ichthyophonus hoferi in spring samples from Prince William Sound within 4 year-classes. Numbers at the top of bars designate numbers of fish examined. Reference lines are at 30\% prevalence for each year-class graph. ND: no data 
major epidemic in the Prince William Sound population spanned 1 yr, from fall 2000 through spring 2001 (Fig. 1, Table 1). By spring 2001, I. hoferi prevalence by histopathology (38\%) was more than 1.5 times greater than in (1) any previous year in Prince William Sound (Table 1) and in (2) any other Alaskan Pacific herring population: Auke Bay (Carls et al. 1998), Bering Sea (Kocan et al. 2004), or Sitka Sound (Table 1). By fall 2001, I. hoferi prevalence had returned to endemic levels (Fig. 1). The peak $I$. hoferi prevalence in spring 2001 was significantly different from the $I$. hoferi prevalence in 2000 and 2002 by histopathology (p < 0.0001 ) and by gross analysis of the heart ( $p=0.038$ for 2000, p < 0.0001 for 2002). Before the epidemic, spring I. hoferi prevalence tended to increase annually within individual year-classes (Fig. 2). During the epidemic, the annual increase in spring $I$. hoferi prevalence was greatest in 2001 for most year-classes. After the epidemic, spring 2002 was the only time in which sample I. hoferi prevalence decreased from the previous year for more than 1 year-class (Fig. 2).

Focused study of 2 fish health variables from 2003 through 2006 documented a second major Ichthyophonus hoferi epidemic in the Prince William Sound population that was longer and more severe than the epidemic in 2000/2001, building steadily from 2003 to 2005 (Table 1). In 2006, the sample prevalence of $I$. hoferi (i.e. white foci in the heart) decreased despite an increase in the mean age of the sampled population (Table 1); however, the decrease from 2005 was not significant $(\mathrm{p}=0.33)$.

\section{Ulcers and VHSV}

Ulcer/VHSV-associated disease in Prince William Sound Pacific herring has mainly affected young herring (Ages $3 \& 4$ ). Outbreaks have oscillated in a roughly 4 yr cycle (Table 3 ), and the amplitude of the ulcer/VHSV index decreased with each cycle after 1993 (Table 3). In all years, the ulcer/VHSV index in Age 3 \& 4 fish was greater than or about equal to the index in Age 5+ fish (Table 3). Observations of ulcers and VHSV in 1993 do not allow for a precise calculation of an ulcer/VHSV index, but available evidence (Meyers et al. 1994) supports the conclusion that the index in 1993 was high (>1.0) for all ages. Therefore, changes in the ulcer/VHSV index provide evidence of a major outbreak in 1993, moderate disease in 1994 and 1998, and mild disease in 1997 and 2002 (Table 3). The population in 1997 and 2002 had 2 similar features. First, these were the years of greatest recruitment of 3-yr-old fish since the 1993 epidemic (Fig. 3). And second, in both years a lower proportion of sampled fish had depleted lipid stores than in the high disease years of 1994 and 1998 (Fig. S2 in the supplement at www.int-res.com/ articles/suppl/d090p001_app. pdf).

Ulcers were not consistently associated with any single pathogen. Skin lesions sometimes contained VHSV, but lesion severity was not clearly associated with the presence of VHSV. For example, in 1994, skin lesions from 4 of 23 fish were tissue culture positive for VHSV (these numbers were incorrectly reported as 5 of 15 in Marty et al. 1998); in only 1 of these fish was

Table 3. Clupea pallasii. Sample size and time series of the prevalence (\%) of Ichthyophonus hoferi, VHSV, severe focal skin reddening (associated with ulcers), and an index combining prevalence of ulcers and VHSV (ulcer/VHSV index; \%) in spring samples from Prince William Sound, Alaska. See Table 1 for sample sizes and prevalence values for all ages of $I$. hoferi and VHSV. I. hoferi prevalence from 1994 to 2002 was determined using histopathology; for 2003 through 2006, prevalence was estimated by doubling the prevalence of gross white foci in the heart (lesions characteristic of $I$. hoferi infection). The ulcer/VHSV index was calculated by multiplying the prevalence of fish with ulcers (lower ulcer bound $=0.5 \%$ ) with the frequency of VHSV+ fish; VHSV was not determined from 2003 to 2006, but was assumed to be the same as in 1999 (based on low ulcer prevalence in these years)

\begin{tabular}{|c|c|c|c|c|c|c|c|c|c|c|c|c|}
\hline \multirow[t]{2}{*}{ Year } & \multirow[b]{2}{*}{$\mathrm{n}$} & \multirow[b]{2}{*}{ I. hoferi } & \multicolumn{3}{|c|}{ Ages $3 \& 4$} & \multirow[b]{2}{*}{$\mathrm{n}$} & \multirow[b]{2}{*}{ I. hoferi } & \multicolumn{3}{|c|}{- Ages 5+ } & \multicolumn{2}{|c|}{ All ages } \\
\hline & & & VHSV & Ulcers & $\begin{array}{l}\text { Ulcer/VHSV } \\
\text { index }\end{array}$ & & & VHSV & Ulcers & $\begin{array}{l}\text { Ulcer/VHSV } \\
\text { index }\end{array}$ & Ulcers & $\begin{array}{c}\text { Ulcer/VHSV } \\
\text { index }\end{array}$ \\
\hline 1994 & 38 & 21.1 & 13.2 & 7.9 & 1.039 & 174 & 23.6 & 3.1 & 2.1 & 0.063 & 3.0 & 0.142 \\
\hline 1995 & 53 & 7.5 & 7.5 & 1.9 & 0.142 & 167 & 26.3 & 0.6 & 4.2 & 0.025 & 3.6 & 0.083 \\
\hline 1996 & 118 & 13.6 & 0.0 & 0.0 & 0.000 & 141 & 26.2 & 0.0 & 2.8 & 0.000 & 1.5 & 0.000 \\
\hline 1997 & 133 & 6.8 & 18.8 & 0.0 & 0.094 & 127 & 26.0 & 10.2 & 0.0 & 0.051 & 0.0 & 0.073 \\
\hline 1998 & 171 & 9.4 & 17.0 & 3.5 & 0.595 & 79 & 35.4 & 6.3 & 2.5 & 0.160 & 3.2 & 0.435 \\
\hline 1999 & 95 & 11.6 & 2.1 & 0.0 & 0.011 & 205 & 30.2 & 0.5 & 1.0 & 0.005 & 0.7 & 0.007 \\
\hline 2000 & 40 & 7.5 & 0.0 & 2.5 & 0.000 & 260 & 23.8 & 0.0 & 0.4 & 0.000 & 0.7 & 0.000 \\
\hline 2001 & 125 & 23.2 & 0.8 & 0.8 & 0.006 & 175 & 48.6 & 2.3 & 0.6 & 0.013 & 0.7 & 0.011 \\
\hline 2002 & 224 & 8.9 & 16.1 & 0.9 & 0.143 & 76 & 32.9 & 7.9 & 0.0 & 0.039 & 0.7 & 0.093 \\
\hline 2003 & 260 & 16.2 & 2.1 & 0.4 & 0.011 & 33 & 60.6 & 0.5 & 0.0 & 0.003 & 0.3 & 0.005 \\
\hline 2004 & 46 & 8.7 & 2.1 & 0.0 & 0.011 & 201 & 32.8 & 0.5 & 0.5 & 0.003 & 0.4 & 0.005 \\
\hline 2005 & 21 & 38.0 & 2.1 & 0.0 & 0.011 & 115 & 55.6 & 0.5 & 0.0 & 0.003 & 0.0 & 0.005 \\
\hline 2006 & 30 & 40.0 & 2.1 & 0.0 & 0.011 & 101 & 39.6 & 0.5 & 0.0 & 0.003 & 0.0 & 0.005 \\
\hline
\end{tabular}




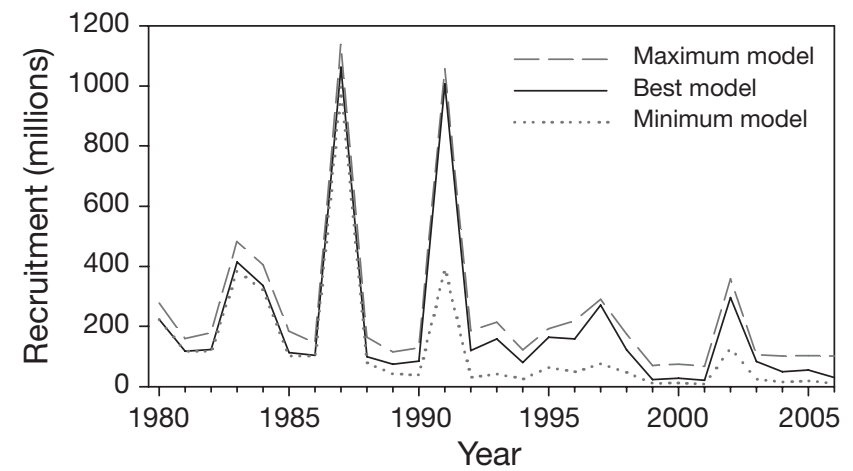

Fig. 3. Clupea pallasii. Estimated recruitment at Age 3 from 25 alternative model scenarios. Results from the best model, the model producing the highest estimates, and the model producing the lowest estimates are shown

the kidney/spleen pool also VHSV positive, and the skin lesion in this fish was scored as mild focal skin reddening. Among the 3 fish in 1994 that had VHSVpositive skin lesions but no VHSV in the kidney/spleen tissue pool, focal skin reddening was scored as mild in 1 fish, moderate in another fish, and severe in the third fish. Differences in the relation of ulcers and VHSV are most obvious for 1997, 1998, and 2002. In all 3 yr, sample prevalence of VHSV was about $14 \%$ (Table 1), but spring ulcer prevalence was greater in 1998 (3.2\%) than in $1997(0 \%)$ or $2002(0.7 \%$; Table 3). As another example, considering the 2463 fish sampled in the spring from Prince William Sound (1994 to 2002), 34 fish had severe focal skin reddening (associated with ulcers); among these 34 fish, 8 (24\%) had moderate or severe Ichthyophonus hoferi infection in the skin or skeletal muscle (1 of these also had colonies of bacterial rods), 6 (18\%) had VHSV isolated from the skin, head kidney, or spleen, and 1 ulcer had rod-shaped or filamentous bacteria. Note that histopathology was done on only 5 of the 34 skin lesions, and filamentous bacteria did not consistently cover ulcers, as was previously incorrectly summarized (Marty et al. 2003). If pathogen:ulcer ratios in these 34 skin lesions are representative of ulcers in Pacific herring, then about $25 \%$ of ulcers are associated with I. hoferi, $20 \%$ with VHSV, $20 \%$ with bacteria, and about one-third are not associated with any pathogen. The lack of a consistent ulcerassociated pathogen supports the conclusion that variables like body condition or stress might be more important in ulcer development than exposure to specific pathogens.

\section{Population modeling of disease}

The best model scenario combined the ulcer/VHSV index for Ages 3 \& 4 with the histopathology prevalence of Ichthyophonus hoferi for all ages combined.

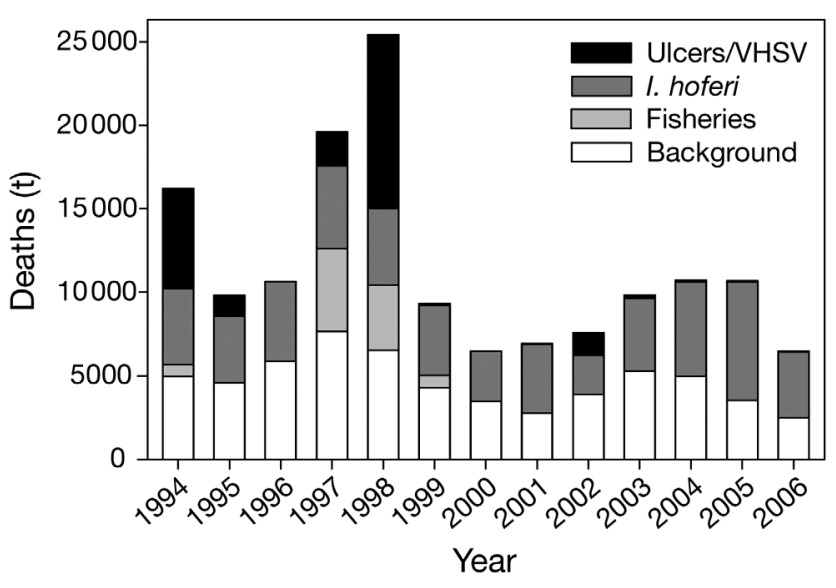

Fig. 4. Clupea pallasii. Annual fish death (metric tons) estimated by the age-structured assessment model for Prince William Sound. Within a year, background mortality is $25 \%$ of the population; fishery mortality is the sum of the spring harvest and the previous fall's harvest; and disease mortality is estimated based on the spring prevalence of (1) Ichthyophonus hoferi for all ages (Table 1) and (2) the ulcer/VHSV index for Ages $3 \& 4$ (Table 3)

This model yielded the smallest (best) value for $\mathrm{AIC}_{\mathrm{C}}$ (Table 2). The $\mathrm{AIC}_{\mathrm{c}}$ value for the model without disease information is significantly larger than for all the models with disease information (Table $2 ; \Delta \mathrm{AIC}_{\mathrm{C}}>4$ ); this indicates that the models with disease information better fit the datasets (Burnham \& Anderson 1998). For most years from 1993 through 2006, the best model scenario estimates that biomass loss associated with disease was greater than or about equal to background mortality (Fig. 4). Estimates of recruitment (Fig. 3) are generally similar among models. The overall pattern in estimated Age 3 recruitment is a strong pulse every 4 yr (1983, 1987, and 1991) and then persistently low numbers after 1992, except for weak peaks in 1997 and 2002.

Survival in relation to disease in Pacific herring is best modeled as a nonlinear process, primarily because it can account for several important variables: age-related differences in disease prevalence, differences in age-class abundance/recruitment, and differential growth among age-classes. Unlike typical linear methods of analysis, the ASA model can be used to estimate sources of disease-associated mortality even when population biomass is increasing. For example, our best-fit model estimates that total prespawning biomass increased from 24300 metric tons in 2002 to 26400 metric tons in 2003 (Table S1 in the supplement at www.int-res.com/articles/suppl/d090p001_app.pdf). This increase was cited as evidence against a 'VHS outbreak' (Elston \& Meyers 2009). The multiple variables and parameters in the model that account for recruitment and various sources of mortality allow us 
to estimate that population biomass in 2003 with no disease would have been 31200 metric tons. Therefore, the best model estimates that population biomass in spring 2003 was $15 \%$ less than expected, and the cause of death can be compartmentalized into Ichthyophonus hoferi (3700 metric tons) and ulcer/VHSV (1200 metric tons) (Table S1).

Initiating a disease study after population decline has been detected by traditional fishery assessment methods can lead to incorrect conclusions about the cause of population decline. For example, population decline associated with the Ichthyophonus hoferi outbreak of 2001 was not detected until 2002. If disease study had been limited to spring 2002, population decline might have been erroneously attributed to the high prevalence of VHSV in 2002. Likewise, population decline detected in 1999 might have been attributed to the I. hoferi prevalence of $24 \%$ in 1999 (Marty et al. 2003). Although this prevalence is high compared with Atlantic herring Clupea harengus populations in Europe (Rahimian \& Thulin 1996, Mellergaard \& Spanggaard 1997), multiyear study confirmed that this prevalence adjusted for age was within normal limits for Prince William Sound (since 1994) and Sitka Sound (1994 to 1997). The model estimates that mortality from I. hoferi in 1998 was significant, but more of the population decline first noticed in 1999 in Prince William Sound was associated with the ulcer/VHSV outbreak of 1998 (Fig. 4).

Model results support the conclusion that agespecific prevalence of Ichthyophonus hoferi underestimates associated annual mortality of Age $3 \& 4$ fish and overestimates associated annual mortality of Age 5+ fish. For example, the spring 2001 I. hoferi prevalence was significantly lower in Age $3 \& 4$ fish (23\%) than in Age 5+ fish ( $49 \%$; Chi-squared $2 \times 2$ contingency table, $\mathrm{p}<0.05$ ), and age differences in $I$. hoferi were similar in most other years (Table 3). Although we might expect age-specific prevalence values to better fit the population abundance data, they do not; but why? We suspect that when I. hoferi is diagnosed by histopathology, Age 3 \& 4 fish die more quickly than Age 5+ fish; i.e. a diagnosis of $I$. hoferi by histopathology is more significant for an Age 3 or 4 fish than for an Age 5+ fish. In the case of spring 2001, the ratio of $I$. hoferi sample prevalence for all ages (38\%) is 1.7 times the sample prevalence in Age $3 \& 4$ fish, but only 0.78 times the sample prevalence in Age 5+ fish. Model results support the conclusion that between sample periods, most infected Age $3 \& 4$ fish die and many other Age $3 \& 4$ fish become infected, whereas only a fraction of the infected Age 5+ fish die, and some infected Age 5+ fish survive until the next sample. The same line of reasoning might explain why the current model using all fish with I. hoferi (by histopathology) is better than the previous iteration of the model (Hulson et al. 2008) that used only fish that had cases of I. hoferi that were moderate or severe. The significant increase in natural mortality since 1992 is better explained by using data that estimate greater mortality (e.g. all $I$. hoferi data) than by using data that estimate less mortality (e.g. limiting data to cases with moderate to severe $I$. hoferi).

A similar explanation might help explain why the ulcer/VHSV index improves the model, whereas neither ulcer nor VHSV prevalence alone improved the model. The index probably accounts for limitations inherent in estimating the effects of disease over an entire year by using samples taken only once per year. Although a single sample contains many nonclinical VHSV cases (Elston \& Meyers 2009), it also fails to account for significant cases of ulcers and VHSV that occur outside the sample period. For example, if ulcers kill most affected fish within a week, and the population maintains an ulcer prevalence of $3 \%$ over a $10 \mathrm{wk}$ outbreak, then total ulcer-associated mortality would be closer to $30 \%$ - not the $3 \%$ prevalence determined from a single sample. We have limited evidence about the expression of VHSV throughout the winter and early spring. In $1995 \mathrm{VHSV}$ prevalence was 12\% among 41 adult fish sampled on 11 April, but none of the 180 fish sampled 2 wk later had VHSV (Table 1). In 1997, VHSV prevalence was nearly the same in fish sampled in late March and mid-April (Table 1). Because most fish infected with VHSV will die or clear the disease in less than a month (Kocan et al. 2001, Elston \& Meyers 2009), many of the infected fish in the prespawning samples of 1995 and 1997 were not infected (or had died) $2 \mathrm{wk}$ later when the spawning samples were collected.

Disease components of the model can be used to predict changes in population biomass. During the past 2 decades, the ASA model was used 3 times in the fall to predict biomass sufficient for a sac roe fishery the following spring (1993, 1994, and 1999) in Prince William Sound. The fishing fleet mobilized to the grounds, but when in-season hydroacoustic analysis revealed unexpectedly low population biomass, the fisheries were never opened. In retrospect, all 3 closures were associated with increased disease prevalence. Early iterations of disease inputs into the ASA model (in 1997) were not robust enough to predict the drop in biomass before the fishery, but the drop was readily explained when it occurred. Since 1999, however, the model has consistently predicted insufficient biomass to support a fishery, and the fleet has never been mobilized in error. Fish biologists and commercial fishermen were alerted as early as 2004 that mortality 'is likely to significantly increase in the next year or 2 as a result of high prevalence of Ichthyophonus hoferi' (21 June 2004 project 
update e-mail sent by G. Marty); increased I. hoferi prevalence in 2005/2006 (Table 1) was consistent with this prediction.

Thus, $13 \mathrm{yr}$ of disease study and population modeling has dramatically increased our understanding of the interaction of disease with changes in population biomass. The present study provides insights, not previously attainable, into the feasibility of estimating natural mortality in age-structured assessment models. Disease information improves our ability to estimate natural mortality and population abundance, and the relative impact of different diseases can be estimated over time. Further, disease information can be used as a cost-effective measure of the population-level significance of multiple environmental stressors; in support, disease information collected in a once-annual assessment by biologists and technicians (2003 to 2006) was sufficient to estimate variable mortality during those years.

\section{Possible causes of recovery failure}

The population model clearly supports the conclusion that, after 1992, recruitment decreased and natural mortality increased. The model cannot prove cause and effect, but variation in population structure from 1993 to 2006 is best described by the addition of disease variables. The best model estimates that the population crashed as a result of disease, and it has remained low ever since as a result of poor recruitment and disease (Figs. 3 to 5). In the projection with no dis-

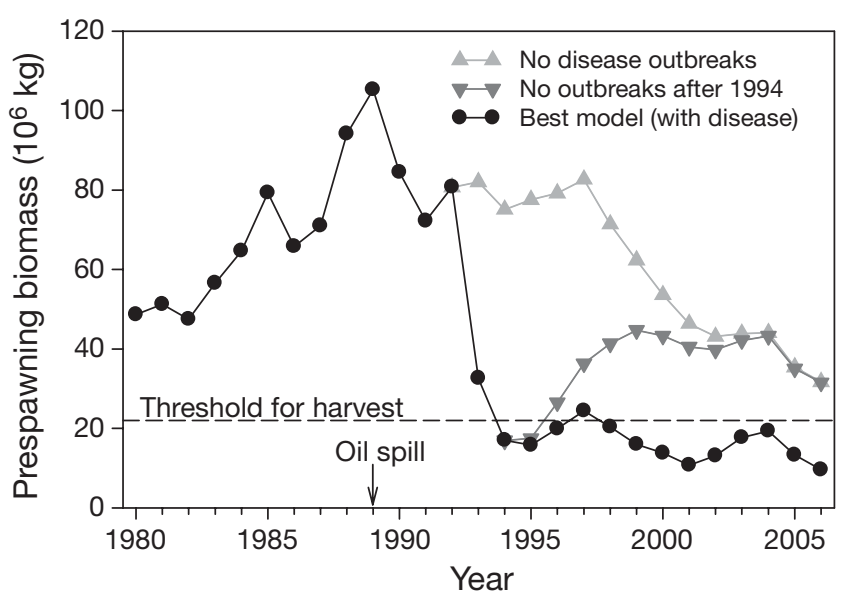

Fig. 5. Clupea pallasii. Estimates of mature Pacific herring biomass in Prince William Sound from the best model or 2 hypothetical scenarios. Alternative scenarios project the biomass as if (1) no disease outbreaks had occurred or (2) outbreaks had ceased after 1994. The 'Exxon Valdez' oil spill occurred in Prince William Sound in 1989. The reference line highlights the biomass threshold below which commercial fisheries are closed ease, the population would have remained stable after 1992, for about $5 \mathrm{yr}$, and then would have commenced a steady decline to around 30000 to 40000 metric tons (Fig. 5), due to weak recruitment. In the projection with disease limited to 1993 and 1994, the crashed population would have gradually recovered by 2004 to the same level as the population without disease (Fig. 5). In the absence of disease since 1994, we hypothesize that by 2006 the Pacific herring population would have been about 3 times larger than our current best model estimate (Fig. 5).

The model also supports the conclusion that the source of disease-associated mortality changed over time (Fig. 4). Total disease-associated mortality from fall 1993 to spring 1998 was estimated to be similar for ulcer/VHSV (19700 metric tons) and Ichthyophonus hoferi (22 800 metric tons), but, from fall 1998 through spring 2006, estimated total mortality associated with $I$. hoferi (34 700 metric tons) was 20 times greater than mortality due to ulcers/VHSV (1800 metric tons; derived from Table S1).

How much of the disease-associated mortality is a result of predation or stress-inducing environmental variables? Both are probably significant, but for stock assessment purposes quantifying these variables might not be needed. Indeed, alternate models that quantify significant environmental stress, predation, or disease in relation to population abundance might simply be measuring association with a different phase of the same process. For example, if fish under environmental stress develop disease and die from predation, then population impacts can be estimated using environmental variables, disease, or predation inputs. Fish populations are continually exposed to a changing environment, endemic pathogens, and predators. The key to developing disease is that the pathogens must infect susceptible hosts. One statistical study reported that the most significant variables related to the lack of recovery of the Prince William Sound Pacific herring population were related to competition or predation by juvenile hatchery pink salmon Oncorhynchus gorbuscha on Pacific herring juveniles; secondary variables included poor nutrition in the winter, ocean (Gulf of Alaska) temperature in the winter, and disease (Deriso et al. 2008). The correlation with pink salmon predation has not been validated with field studies, but our study validates the association with disease.

For estimating population change, it might be more cost effective to measure disease than other related variables. The complexity of environmental variables makes their quantification expensive and the interpretation of their significance difficult. The social value of many Pacific herring predators (e.g. marine mammals and birds) renders their sampling for research legally difficult or impossible. By comparison, we show that 
gross analysis of only 2 variables - ulcers and white foci in the heart-is sufficient to estimate disease in Pacific herring.

Does persistent disease play an important role in population collapse and failed recovery of other fish populations? Fishery collapse is often attributed to overfishing, pollution, and habitat destruction (Holmlund \& Hammer 1999, Jackson et al. 2001, Worm et al. 2006), but disease is only rarely investigated as a possible cause. Documented cases include the impact of sea lamprey Petromyzon marinus on lake trout Salvelinus namaycush in the North American Great Lakes (Coble et al. 1990), Ichthyophonus hoferi on decreased survival of reproductively important mature female Pacific herring near Cherry Point, Washington, USA (Hershberger et al. 2002), and Gyrodactlyus salaris on young Atlantic salmon Salmo salar in Norwegian rivers (Heggberget \& Johnsen 1982). For Pacific herring in Prince William Sound, Alaska, neither toxin exposure nor overfishing is limiting recovery (Marty et al. 1999, Hulson et al. 2008). Direct exposure to 'Exxon Valdez' oil ceased within a year of the 1989 oil spill, and commercial fisheries have been closed for more than a decade. We postulate that Pacific herring population biomass will not recover to support both predators and harvest fisheries until conditions that lead to disease no longer dominate population dynamics. Validation of this hypothesis will require continued monitoring until the population recovers.

Acknowledgements. We thank N. J. Del Pesco, J. O'Rourke, F. C. Teh, and T. Harrington for technical assistance. T. R. Meyers oversaw cell culture for virus analysis; some necropsies were performed by J. Odani; D. Marty and M. Díez Padrisa reviewed the manuscript. The work was supported jointly by the US National Science Foundation Grant Nos 9871982 and 9901351, and by the 'Exxon Valdez' Oil Spill Trustee Council through contracts with the Alaska Department of Fish and Game and the US National Oceanic and Atmospheric Administration.

\section{LITERATURE CITED}

- Anderson DR, Burnham KP, White GC (1998) Comparison of Akaike information criterion and consistent Akaike information criterion for model selection and statistical inference from capture-recapture studies. J Appl Stat 25: 263-282

Avendaño-Herrera R, Toranzo AE, Magariños B (2006) Tenacibaculosis infection in marine fish caused by Tenacibaculum maritimum: a review. Dis Aquat Org 71: 255-266

Burnham KP, Anderson DR (1998) Model selection and inference. Springer-Verlag, New York, NY

> Carls MG, Marty GD, Meyers TR, Thomas RE, Rice SD (1998) Expression of viral hemorrhagic septicemia virus in prespawning Pacific herring (Clupea pallasi) exposed to weathered crude oil. Can J Fish Aquat Sci 55:2300-2309
Carls MG, Marty GD, Hose JE (2002) Synthesis of the toxicological impacts of the Exxon Valdez oil spill on Pacific herring (Clupea pallasi) in Prince William Sound, Alaska, USA Can J Fish Aquat Sci 59:153-172

Coble DW, Bruesewitz RE, Fratt TW, Scheirer JW (1990) Lake trout, sea lampreys, and overfishing in the upper GreatLakes - a review and reanalysis. Trans Am Fish Soc 119: 985-995

Daniel GE (1933) Studies on Ichthyophonus hoferi, a parasitic fungus of the herring, Clupea harengus. I. The parasite as it is found in the herring. Am J Hyg 17:262-276

Davis CR, Marty GD, Adkison MA, Freiberg EF, Hedrick RP (1999) Association of plasma IgM with body size, histopathologic changes, and plasma chemistries in adult Pacific herring Clupea pallasi. Dis Aquat Org 38:125-133

Deriso RB, Maunder MN, Pearson WH (2008) Incorporating covariates into fisheries stock assessment models with application to Pacific herring. Ecol Appl 18:1270-1286

Efron B, Tibshirani RJ (1993) An introduction to the bootstrap. Chapman \& Hall, New York, NY

Elston RA, Meyers TR (2009) Effect of viral hemorrhagic septicemia virus on Pacific herring in Prince William Sound, Alaska, from 1989 to 2005. Dis Aquat Org 83:223-246

Fournier D (1996) An introduction to AD model builder for use in nonlinear modeling and statistics. Otter Research, Nanaimo, BC

Foy RJ, Norcross BL (2001) Temperature effects on zooplankton assemblages and juvenile herring feeding in Prince William Sound, Alaska. In: Funk F, Blackburn J, Hay D, Paul AJ, Stephensen R, Toreson R, Witherell D (eds) Herring: expectations for a new millennium. AK-SG-01-04, University of Alaska Sea Grant, Fairbanks, AK, p 21-35

Gozlan RE, St-Hilaire S, Feist SW, Martin P, Kent ML (2005) Biodiversity: disease threat to European fish. Nature 435: 1046

> Heggberget TG, Johnsen BO (1982) Infestations by Gyrodactylus sp. of Atlantic salmon, Salmo salar L., in Norwegian rivers. J Fish Biol 21:15-26

> Hershberger PK, Stick K, Bui B, Carroll C and others (2002) Incidence of Ichthyophonus hoferi in Puget Sound fishes and its increase with age of adult Pacific herring. J Aquat Anim Health 14:50-56

> Holmlund CM, Hammer M (1999) Ecosystem services generated by fish populations. Ecol Econ 29:253-268

> Hulson PJF, Miller SE, Quinn TJ II, Marty GD, Moffitt SD, Funk F (2008) Data conflicts in fishery models: incorporating hydroacoustic data into the Prince William Sound Pacific herring assessment model. ICES J Mar Sci 65: $25-43$

> Jackson JBC, Kirby MX, Berger WH, Bjorndal KA and others (2001) Historical overfishing and the recent collapse of coastal ecosystems. Science 293:629-638

Kocan RM, Marty GD, Okihiro MS, Brown ED, Baker TT (1996) Reproductive success and histopathology of individual Prince William Sound herring 3 years after the Exxon Valdez oil spill. Can J Fish Aquat Sci 53:2388-2393

- Kocan R, Bradley M, Elder N, Meyers T, Batts W, Winton J (1997) The North American strain of viral hemorrhagic septicemia virus is highly pathogenic for laboratory reared Pacific herring. J Aquat Anim Health 9:279-290

- Kocan RM, Hershberger P, Mehl T, Elder N, Bradley M, Wildermuth D, Stick K (1999) Pathogenicity of Ichthyophonus hoferi for laboratory-reared Pacific herring Clupea pallasi and its early appearance in wild Puget Sound herring. Dis Aquat Org 35:23-29

> Kocan RM, Hershberger PK, Elder NE, Winton JR (2001) Epidemiology of viral hemorrhagic septicemia among juve- 
nile Pacific herring and Pacific sand lance in Puget Sound, Washington. J Aquat Anim Health 13:77-85

Kocan R, Hershberger P, Winton J (2004) Ichthyophoniasis: an emerging disease of Chinook salmon of the Yukon River. J Aquat Anim Health 16:58-72

Lumsden JS, Morrison B, Yason C, Russell S and others (2007) Mortality event in freshwater drum Aplodinotus grunniens from Lake Ontario, Canada, associated with viral haemorrhagic septicemia virus, Type IV. Dis Aquat Org 76:99-111

Marty GD, Freiberg EF, Meyers TR, Wilcock J, Farver TB, Hinton DE (1998) Viral hemorrhagic septicemia virus, Ichthyophonus hoferi, and other causes of morbidity in Pacific herring Clupea pallasi spawning in Prince William Sound, Alaska, USA. Dis Aquat Org 32:15-40

> Marty GD, Okihiro MS, Brown ED, Hanes D, Hinton DE (1999) Histopathology of adult Pacific herring in Prince William Sound, Alaska, after the Exxon Valdez oil spill. Can J Fish Aquat Sci 56:419-426

- Marty GD, Quinn TJ II, Carpenter G, Meyers TR, Willits NH (2003) Role of disease in abundance of a Pacific herring (Clupea pallasi) population. Can J Fish Aquat Sci 60: $1258-1265$

Mellergaard S, Spanggaard B (1997) An Ichthyophonus hoferi epizootic in herring in the North Sea, the Skagerrak, the Kattegat and the Baltic Sea. Dis Aquat Org 28:191-199

Meyers TR, Winton JR (1995) Viral hemorrhagic septicemia virus in North America. Annu Rev Fish Dis 5:3-24

Meyers TR, Short S, Lipson K, Batts WN, Winton JR, Wilcock J, Brown E (1994) Association of viral hemorrhagic septicemia virus with epizootic hemorrhages of the skin in Pacific herring Clupea harengus pallasi from Prince William Sound and Kodiak Island, Alaska, USA. Dis Aquat Org 19:27-37

Moles AD, Rice SD, Okihiro MS (1993) Herring parasite and tissue alterations following the Exxon Valdez oil spill 1993 International Oil Spill Conference (prevention, preparedness, response). United States Coast Guard, American Petroleum Institute and US Environmental Protection Agency, Tampa, FL, p 325-328

Overton AS, Margraf FJ, Weedon CA, Pieper LH, May EB (2003) The prevalence of mycobacterial infections in striped bass in Chesapeake Bay. Fish Manage Ecol 10: 301-308

Editorial responsibility: Julie Bebak, Auburn, Alabama, USA
Pearson WR, Elston RA, Bienert RW, Drum AS, Antrim LD (1999) Why did the Prince William Sound, Alaska, Pacific herring (Clupea pallasi) fisheries collapse in 1993 and 1994? Review of the hypotheses. Can J Fish Aquat Sci 56: 711-737

Quinn TJ II, Deriso RB (1999) Quantitative fish dynamics. Oxford University Press, New York, NY

Quinn TJ II, Marty GD, Wilcock J, Willette M (2001) Disease and population assessment of Pacific herring in Prince William Sound, Alaska. In: Funk F, Blackburn J, Hay D, Paul AJ, Stephensen R, Toreson R, Witherell D (eds) Herring: expectations for a new millennium. AK-SG-01-04, University of Alaska Sea Grant, Fairbanks, AK, p 363-379

> Rahimian H, Thulin J (1996) Epizootiology of Ichthyophonus hoferi in herring populations off the Swedish west coast. Dis Aquat Org 27:187-195

Sindermann CJ (1958) An epizootic in Gulf of St. Lawrence fishes. Trans N Am Wildl Conf 23:349-360

Skall HF, Olesen NJ, Mellergaard S (2005) Viral haemorrhagic septicaemia virus in marine fish and its implications for fish farming: a review. J Fish Dis 28:509-529

Suryan RM, Irons DB, Brown ED, Jodice PGR, Roby DD (2006) Site-specific effects on productivity of an upper trophiclevel marine predator: bottom-up, top-down, and mismatch effects on reproduction in a colonial seabird. Prog Oceanogr 68:303-328

> Thorne RE, Thomas GL (2008) Herring and the 'Exxon Valdez' oil spill: an investigation into historical data conflicts. ICES J Mar Sci 65:44-50

Whittington RJ, Crockford M, Jordan D, Jones B (2008) Herpesvirus that caused epizootic mortality in 1995 and 1998 in pilchard, Sardinops sagax neopilchardus (Steindachner), in Australia is now endemic. J Fish Dis 31:97-105

Williams EH, Quinn TJ II (2000) Pacific herring, Clupea pallasi, recruitment in the Bering Sea and Northeast Pacific Ocean, II: Relationships to environmental variables and implications for forecasting. Fish Oceanogr 9:300-315

- Womble JN, Willson MF, Sigler MF, Kelly BP, VanBlaricom GR (2005) Distribution of Steller sea lions Eumetopias jubatus in relation to spring-spawning fish in SE Alaska. Mar Ecol Prog Ser 294:271-282

Worm B, Barbier EB, Beaumont N, Duffy JE and others (2006) Impacts of biodiversity loss on ocean ecosystem services. Science 314:787-790

Submitted: February 2, 2009; Accepted: January 29, 2010 Proofs received from author(s): May 11, 2010 